\title{
ORANG TUA, SEKOLAH DAN KEMAJUAN TEKNOLOGI INFORMASI DAN KOMUNIKASI TERHADAP PERKEMBANGAN ANAK
}

Oleh: Gusar Siahaan *)

\section{Abstrak}

Pendidikan sebagai suatu upaya peningkatan kualitas sumber daya manusia merupakan faktor penting dalam pembangunan bangsa dan negara Indonesia. Oleh karena itu, bidang pendidikan dijadikan sebagai salah satu prioritas dalam pembangunan nasional yang diharapkan dapat meningkatkan kualitas manusia Indonesia, yaitu manusia yang cerdas, terampil dan bertanggung jawab terhadap diri sendiri, keluarga dan masyarakat serta bertaqwa kepada Tuhan Yang Maha Esa. Sosok keberhasilan manusia Indonesia di masa yang akan datang ditentukan oleh keberhasilan anak-anak sebagai generasi muda yang harus mampu bersaing dalam menghadapi tantangan hidup yang semakin kompleks. Untuk dapat mewujudkannya diperlukan peranserta dari berbagai pihak dan salah satu di antaranya adalah peranserta pihak orang tua. Orang tua dituntut untuk mewujudkan peranan dan tanggungjawabnya sebaik mungkin dalam mendidik anak-anaknya. Para orang tua hendaknya mulai mengenal dan memahami tantangan hidup yang akan dihadapi anak dengan cara membekali anak-anaknya dengan pendidikan yang bermutu. Peranan orang tua dalam membimbing, mengawasi dan membantu anak dalam proses belajamya haruslah dilakukan seintensif mungkin karena keberhasilan pendidikan anak sangat banyak ditentukan oleh peranan orang tua. Di samping itu, sekolah (baca: guru) merupakan mitra orang tua dalam proses pengembangan potensi diri anak. Kemajuan teknologi informasi dan komunikasi (TIK) juga

\section{A. PENDAHULUAN}

Harapan orang tua dalam mendidik anakanaknya adalah memiliki anak-anak yang pintar, sopan, berbakti, pandai bergaul, dan sukses. Bagaimana peranan orang tua untuk mewujudkan harapan yang diinginkan, itulah yang paling penting. Bahkan banyak orang tua yang menilai bahwa materi pelajaran yang diperoleh anak-anaknya di sekolah tidak memadai sehingga orang tua berupaya untuk memberikan berbagai les tambahan untuk anak-anaknya.
Dalam urusan pendidikan anak, sudah seharusnya orang tua menempatkannya pada urutan pertama karena para orang tua yang paling mengerti benar mengenai sifatsifat baik dan buruk anak-anaknya; demikian juga dengan hal-hal yang disukai dan yang tidak disukai oleh anak-anak. Para orang tua adalah orang yang pertama kali tahu bagaimana perkembangan karakter dan kepribadian anak-anaknya. Para orang tua jugalah yang harus bekerja keras mendidik anak-anak mereka agar menjadi orang yang memiliki kepribadian yang baik.

*) Gusar Siahaan adalah guru mata pelajaran Teknologi Informasi dan Komunikasi (TIK) pada Sekolah Menengah Pertama (SMP) dan Sekolah Menengah Atas (SMA) Don Bosco Pondok Indah, Jakarta Selatan. 
Mengingat pada masa peralihan, anak-anak lebih banyak membutuhkan perhatian dan kasih sayang, maka para orang tua tidak dapat menyerahkan sepenuhnya tanggung jawab yang demikian ini kepada guru di sekolah. Apabila anak berada dalam perkembangan jiwa yang masih rapuh dan labil kurang mendapat perhatian dan kasih sayang dari orang tua kemungkinan akan dapat mengakibatkan pengaruh buruk terhadap perkembangan jiwa anak. Banyaknya tindakan kriminal yang dilakukan generasi muda dewasa ini tidak terlepas dari kelengahan bahkan ketidakpedulian para orang tua dalam mendidik mereka, mulai dari usia dini.

Dalam perkembangan jiwa, terdapat periodeperiode kritis yang sangat berarti dan memerlukan perhatian serius. Apabila periode-periode kritis ini tidak dapat dilalui dengan baik, maka akan timbul berbagai gejala yang menunjukkan keterlambatan, ketegangan, kesulitan penyesuaian diri, dan kepribadian yang terganggu. Lebih jauh lagi, tugas sebagai makhluk sosial untuk saling berhubungan dengan sesama, baik untuk kepentingan diri sendiri maupun untuk kepentingan orang lain di lingkungannya akan mengalami kegagalan.

Orang tua dan sekolah (baca: guru) merupakan dua unsur yang saling berkaitan dan memiliki keterkaitan yang kuat satu sama lain. Terlepas dari beragamnya asumsi masyarakat, ungkapan "buah tak akan pernah jatuh jauh dari pohonnya" adalah sebuah gambaran tentang betapa kuatnya pengaruh orang tua terhadap perkembangan potensi anaknya. Agar tidak salah dalam mendidik anak, dituntut adanya hubungan kerjasama yang baik antara orang tua dan sekolah. Orang tua mendidik anaknya di rumah, dan kemudian di sekolah, para guru mempunyai peranan dan tanggung jawab untuk melanjutkan pendidikan anak. Agar kerjasama di antara orang tua dan sekolah dapat berjalan dengan baik, maka kedua pihak ini harus berada dalam rel yang sama, seiring seirama dalam memperlakukan anak, baik sewaktu mereka berada di rumah maupun sewaktu mereka juga di sekolah.
Apabila kegiatan pendidikan anak hanya didasarkan pada kemauan salah satu pihak saja, misalnya pihak keluarga atau pihak sekolah saja, maka berdasarkan pengalaman, keadaan yang demikian ini tidak akan berjalan baik. Atau dengan kata lain, usaha yang hanya dilakukan oleh orang tua atau sekolah saja tidak akan banyak bermanfaat karena ada dua rel yang harus dilalui oleh anak. Akibatnya, si anak akan mengalami kebingungan dalam menentukan siapa yang harus mereka turuti. Bahkan dampak yang lebih jauh lagi, ada kekhawatiran bahwa di dalam diri anak akan terbentuk karakter atau kepribadian ganda.

Memang adakalanya tidak mudah untuk melaksanakan kesepahaman namun apabila kedua pihak didasari oleh perasaan kasih sayang kepada anak, maka sesulit apapun usaha yang dituntut, tentunya dengan ketulusan hati, kedua pihak akan dapat melakukannya. Dengan perasaan kasih sayang akan dapat mengubah yang pahit menjadi manis, debu beralih menjadi emas, keruh menjadi bening, sakit menjadi sembuh, penjara menjadi telaga, derita menjadi nikmat, dan kemarahan menjadi rahmat.

Kesamaan pemahaman yang dikembangkan oleh pihak orang tua dan sekolah merupakan modal besar dalam mendidik anak. Setiap peristiwa yang terjadi atau yang dialami anak, baik di rumah maupun di sekolah hendaknya dicatat secara baik atau cermat oleh kedua belah pihak. Ketika seandainya terjadi hal-hal yang janggal pada diri anak, maka catatancatatan yang telah dibuat akan sangat bermanfaat untuk digunakan oleh kedua pihak sebagai bahan melakukan evaluasi mengenai perubahan-perubahan yang dialami anak, baik mengenai sifat jeleknya maupun sifat bagusnya. Berdasarkan catatan-catatan ini, kedua belah pihak dapat menentukan langkah-langkah berikutnya yang perlu ditempuh.

Setiap ada sesuatu yang dirasakan janggal terjadi dalam diri anak atau anak memperlihatkan prilaku yang janggal, baik di rumah maupun di sekolah, maka orang tua atau guru dituntut untuk sesegera mungkin menanganinya dengan cara saling menginformasikan kejanggalan yang terjadi 
pada diri anak. Akan lebih baik lagi apabila pihak orang tua dan sekolah dapat mendiskusikannya lebih lanjut sehingga masalah yang dihadapi anak dapat dengan cepat tertangani dan tidak berlarut-larut. Itulah sebabnya, sebagaimana yang telah dikemukakan sebelumnya bahwa orang tua dan sekolah merupakan satu kesatuan yang utuh di dalam mendidik anak.

Untuk mencapai cita-cita orang tua atau sekolah mengenai pendidikan anak, dituntut adanya sikap yang konsisten dari kedua belah pihak dalam melaksanakan programprogram yang telah disepakati bersama, terutama di era teknologi informasi dan komunikasi (TIK) yang berkembang pesat dewasa ini. Kemajuan TIK terutama televisi dan internet sudah merambah sebagian besar aspek kehidupan sehari-hari manusia (Siahaan, 2006). Anak-anak dalam masa pertumbuhan/ perkembangan dirinya tidak terlepas dari pengaruh kemajuan TIK, baik yang bersifat positif maupun negatif. Sehubungan dengan hal ini, peranan orang tua sangat besar dan menentukan dalam mengarahkan anak memanfaatkan televisi dan internet sehingga memberikan kontribusi positif terhadap perkembangan diri anak. Sebagaimana dikemukakan oleh para ahli bahwa TIK adalah bagaikan sebuah pedang bermata dua, di satu sisi dapat memberikan manfaat (positif) dan sekaligus di sisi yang lain dapat memberikan dampak negatif (mudharat). Tulisan ini dimaksudkan untuk berbagi pemikiran tentang peranan orang tua dan guru serta pengaruh kemajuan TIK (televisi dan internet) dalam pertumbuhan/ perkembangan anak.

\section{B. KAJIAN PUSTAKA}

\section{Lingkungan Pendidikan Anak}

Lingkungan pendidikan anak dimulai dari rumah dan kemudian sekolah serta lingkungan tempat anak berada. Kunci menuju pertumbuhan dan perkembangan anak yang baik adalah keterlibatan orang tua yang penuh perhatian. Jika orang tua terlibat langsung dalam pendidikan anakanak di sekolah, maka prestasi anak akan meningkat. Pada umumnya, setiap siswa yang berprestasi dan berhasil dengan baik menamatkan pendidikannya berasal dari keluarga yang orangtuanya selalu bersikap mendukung. Beberapa hal yang dapat dilakukan orang tua bagi pertumbuhan dan perkembangan anaknya adalah (a) mendukung anak dalam kegiatan belajarnya, (b) bekerjasama dengan guru, (c) menyediakan waktu untuk anak, (d) mengawasi kegiatan belajar anak di rumah, (e) membimbing anak untuk bertanggung jawab, (f) menegakkan disiplin dalam kehidupan sehari-hari di rumah, dan (g) menjadi teman yang baik bagi anak (http://kumpulan.info/keluarga/ anak/40-anak/192-pendidikan-yang-baikuntuk-anak. html. Diakses 20 Agustus 2009).

Pemikiran lain yang tidak jauh berbeda dengan pemikiran sebelumnya adalah bahwa peranan orang tua dalam proses pertumbuhan dan perkembangan anak adalah: (a) memelihara dan membina anak agar menjadi manusia yang takut akan Tuhan, (b) membina moral anak menjadi manusia yang punya tanggung jawab, kemampuan intelektual yang tinggi, rasa hormat dan etika sopansantun, (c) melatih kemandirian anak agar siap dan mampu melakukan peran sebagai pemimpin di masa yang akan datang, dan (d) mendukung anak untuk mengaktualisasikan diri di lingkungan sosialnya. (http://www.gobatak.com. Diakses pada tanggal 20 Agustus 2009).

Seiiring dengan perkembangan yang terjadi di era globalisasi, waktu untuk berkumpul dengan keluarga di rumah dirasakan sangat sedikit atau hampir tidak ada. Dengan kesibukan orang tua yang sangat padat, seringkali pendidikan anak diserahkan kepada pihak ketiga yaitu pembantu (baby sitter), guru les privat atau keluarga dekat. Pendidikan yang seperti ini membuat anak tumbuh dan berkembang seadanya; artinya kualitas pendidikan anak tergantung pada kondisi pihak ketiga tersebut.

Orang tua adalah penanggung jawab utama dalam pendidikan anak. Sedangkan sekolah atau guru adalah 
penerima tanggung jawab dari orang tua yang tentu saja akan bertanggung jawab pada tugasnya untuk mengajar dan mendidik anak didiknya selama berada bersama-sama di lingkungan sekolah. Di sekolah, guru memikirkan, memilih, dan memanfaatkan sarana, bahan dan metode untuk dimanfaatkan sebaikbaiknya bagi kepentingan pembelajaran anak.

Sedangkan di rumah, para orang tua mendukung proses pendidikan yang telah diterima anak dari gurunya di sekolah, dengan cara (a) membimbing dan mengajar anak untuk terus melanjutkan apa yang sudah diberikan guru di sekolah, (b) menemukan minat anak yang hasilnya dapat dikomunikasikan dengan pihak sekolah, (c) mengkomunikasikan masalah-masalah pendidikan sekolah anak dengan pihak sekolah, dan (d) memperhatikan faktor-faktor yang mempengaruhi hasil belajar anak. Oleh karena itu, kerja sama antara orang tua dan guru sangatlah penting terlebih-lebih lagi dalam menghadapi kemajuan TIK yang sangat pesat.

Salah satu dampak dari perkembangan TIK yang sangat pesat adalah penggunaannya yang tidak dilakukan untuk yang semestinya. Kemajuan TIK yang paling sering digunakan dan mudah dijangkau oleh para remaja dan anak muda dewasa ini adalah mengakses internet. Sekalipun pemerintah sudah mengundangkan undang-undang tentang anti pornoaksi dan pornografi tetapi para remaja/ generasi muda masih saja kerap mengakses konten yang berbau negatif yang dapat merusak moral mereka. Teknologi canggih yang semestinya diciptakan untuk menambah pengetahuan dan memperluas wawasan malah dapat berakibat pada kemerosotan moral.

Pergaulan merupakan interaksi antara beberapa orang, baik dalam lingkup kekeluargaan, organisasi, maupun masyarakat. Melalui pergaulan, seseorang akan berkembang karena dapat belajar tentang banyak hal termasuk tata cara bergaul. Pergaulan menjadikan individu yang bersosial karena pada dasarnya manusia adalah makhluk individu sekaligus juga makhluk sosial. Namun pergaulan di era modernisasi yang diwarnai oleh kemajuan TIK yang pesat telah banyak disalah-gunakan terutama di kalangan anak-anak muda sehingga berkembanglah istilah pergaulan bebas (pergaulan yang negatif).

Pergaulan yang negatif merupakan salah satu dari berbagai penyebab kehancuran hidup para remaja dan generasi muda. Dewasa ini dapat diamati betapa banyaknya sistem pergaulan kawula muda yang mengadopsi gaya hidup ala barat (westernisasi) di mana etika pergaulan ketimuran cenderung perlahan-lahan pupus. Salah satu eksesnya adalah "perkawinan karena kecelakaan" (married by accident). Married by Accident (MBA) tampaknya sudah menjadi tren di kalangan remaja/ generasi muda di mana melakukan hubungan seks sebelum menikah mulai banyak dilakukan pada saat pacaran. Di beberapa media massa pernah diberitakan tentang anak-anak muda yang tidak segan-segan untuk merekam adegan mesum yang mereka lakukan untuk disebarluaskan melalui fasilitas handphone.

Permasalahan lain yang menakutkan para orang tua adalah narkoba karena berbahaya dan merusak kehidupan generasi muda. Narkoba menjadi jurang kehancuran bagi anak, remaja dan generasi muda. Ironisnya, mengkonsumsi barang haram ini "tampaknya cenderung mulai ngetren" di kalangan remaja/ generasi muda akhir-akhir ini. Apabila mengkonsumsi barang ini maka remaja/ generasi muda akan dapat menikmati perasaan "senang" atau yang dikenal dengan bahasa gaulnya (fly).

Sebenarnya sudah sering disosialisasikan secara jelas dan luas oleh para ahli kesehatan bahwa mengkonsumsi barang-barang sejenis 
narkoba akan sangat fatal karena merusak sistem syaraf. Selain itu, seseorang yang mengkonsumsi barang sejenis narkoba ini akan mengakibatkan terjadinya perasaan ketagihan (addicts) dan ketergantungan. Keadaan yang demikian inilah yang sungguhsungguh menakutkan terutama para orang tua.

Tentunya tidak ada satu pun orang tua di dunia ini yang menginginkan masa depan anaknya hancur karena kesalahan yang tidak semestinya terjadi. Di sinilah tampak peran penting orang tua dalam mengontrol dan mengawasi perkembangan hidup anaknya. Menjadi orang tua bukanlah hanya soal siapa kita, tetapi yang jauh lebih penting adalah apa yang dilakukan. Pengasuhan anak tidak hanya mencakup tindakan tetapi juga mencakup apa yang dikehendaki agar anak mengerti makna secara baik dalam menjalani kehidupan sehari-hari.

Semua orang tua pastilah menghendaki yang terbaik bagi anak-anaknya. Orang tua ingin mendisiplinkan, mendorong, dan menasehati anak-anaknya agar mereka berhasil menjalani kehidupan dari semenjak masa kanak-kanak sampai dengan dewasa. Orang tua menghendaki agar anak-anaknya menjadi yang terbaik dalam hal apapun. Banyak orang tua tidak jemu-jemunya mendorong anakanaknya untuk melakukan hal yang terbaik dalam kehidupannya, termasuk membentuk sang buah hati untuk menikmati kebebasan mengeluarkan pendapat, menggali bakat, dan mengembangkan minat. Di sisi lain, anak juga ingin mendapat perhatian dari kedua orang tuanya. Dalam kaitan ini, ahli psikologi sering sekali menganjurkan agar para orang tua tidak membeda-bedakan anak yang satu dengan yang lainnya dalam pola pengasuhan anak. Sejatinya kita juga tidak semestinya membeda-bedakan mereka, baik dalam mendidik maupun memberikan perhatian.

Sebagai orang tua yang baik, hendaknya tidak terbatas hanya melihat keburukan atau kebaikan tetapi juga harus melihat tata cara pergaulan sang anak, dengan siapa anak bergaul, dan bagaimana pergaulannya. Bukan sekedar membatasi sang anak bergaul namun diharapkan bahwa impian atau citacita orang tua untuk menyaksikan anaknya menggapai sukses mengarungi kehidupan tanpa mengalami kesalahan dalam pergaulan, baik di dalam maupun di luar lingkungan keluarga, menjadi sebuah kenyataan. Manfaat yang dapat dipetik dari hasil pengasuhan yang baik terhadap anak adalah sepenuhnya berpulang kembali kepada orang tua, apakah anak yang berada dalam pengasuhannya dapat berkembang menjadi orang yang menghargai orang tua.

\section{Pengaruh Televisi dan Internet terhadap Perkembangan Anak}

Dalam berbagai hal, penggunaan istilah teknologi informasi dan komunikasi disamakan dengan media. Itulah sebabnya dikatakan bahwa internet adalah salah satu dari contoh dari TIK dan internet juga dikatakan sebagai salah satu jenis media (lebih spesifik lagi sebagai media jaringan). Dalam pembahasan lebih lanjut, kedua istilah ini akan digunakan secara silih berganti. Jenis media yang akan dibahas dibatasi pada media internet dan televisi dengan pertimbangan bahwa kedua jenis media ini merupakan media yang sangat banyak digunakan dalam kehidupan sehari-hari. Pengertian media secara sederhana dapat dikatakan sebagai sarana, perantara, wahana, atau saluran yang digunakan untuk menyampaikan atau mendapatkan sesuatu kepada dan dari seseorang.

Proses belajar-mengajar pada hakekatnya adalah proses komunikasi, penyampaian pesan dari pemberi kepada penerima. Pesan berupa isi/ajaran yang dituangkan ke dalam simbol-simbol komunikasi baik verbal (kata-kata dan tulisan) maupun non-verbal, proses ini dinamakan encoding sedang penafsiran simbol-simbol komunikasi tersebut oleh peserta didik dinamakan decoding. Dalam memahami apa yang didengar, dibaca, dilihat atau diamati adakalanya penafsiran berhasil dan adakalanya tidak. Kegagalan/ketidakberhasilan atau penghambat dalam proses komunikasi dikenal dengan istilah barriers atau noise. Semakin banyak verbalisme semakin abstrak pemahaman yang diterima. 
Secara umum, media menurut Soeparno mempunyai kegunaan, yaitu:

a. memperjelas pesan agar tidak terlalu verbalistis.

b. mengatasi keterbatasan ruang, waktu tenaga dan daya indra.

c. menimbulkan gairah belajar, interaksi lebih langsung antara murid dengan sumber belajar.

d. memungkinkan anak belajar mandiri sesuai dengan bakat dan kemampuan visual, auditori dan kinestetiknya.

e. memberi rangsangan, pengalaman dan menimbulkan persepsi yang sama (Soeparno, 1988).

Sedangkan Kemp and Dayton mengemukakan beberapa kontribusi media pembelajaran, yaitu sebagai berikut:

a. Penyampaian pesan pembelajaran dapat lebih terstandar.

b. Pembelajaran dapat lebih menarik.

c. Pembelajaran menjadi lebih interaktif dengan menerapkan teori belajar.

d. Waktu pelaksanaan pembelajaran dapat diperpendek.

e. Kualitas pembelajaran dapat ditingkatkan.

f. Proses pembelajaran dapat berlangsung kapanpun dan dimanapun diperlukan.

g. Sikap positif peserta didik terhadap materi pembelajaran serta proses pembelajaran dapat ditingkatkan.

h. Peranan guru berubahan kearah yang positif (Kemp and Dayton, 1985).

Sebagaimana yang telah dikemukakan sebelumnya bahwa jenis TIK yang akan dibahas di dalam tulisan ini adalah terbatas hanya mengenai televisi dan internet serta dampaknya terhadap perkembangan anak.

a. Televisi

Perkembangan dunia informasi telah menghasilkan beberapa inovasi yang menakjubkan. Televisi adalah salah satu di antaranya yang telah menuai sukses besar. Sejak ditemukannya pada permulaan abad ke-19, maka kini kita dapat menikmati berbagai peristiwa yang terjadi di berbagai belahan dunia hanya dengan memencet tombol-tombol kotak elektronik tersebut di rumah. Televisi telah menjadi kebutuhan pokok masyarakat, bahkan tidak jarang terdapat lebih dari satu televisi di dalam satu rumah tangga.

Kita dapat mengetahui berita terkini yang terjadi di berbagai belahan dunia dalam waktu yang sangat singkat. Sebagai contoh, peristiwa pemboman WTC di New York beberapa tahun lalu, hanya selang beberapa menit setelah peristiwa itu berlangsung, kita bisa mengetahui perkembangan terakhirnya dari stasiun televisi CNN (saluran khusus program berita). Bahkan, kita pun bisa melihat secara langsung berbagai pertandinganpertandingan olahraga internasional seperti World Cup Football, Tennis Wimbledon, Kejuaraan Bulutangkis All England, pertandingan basket NBA dan masih banyak lagi kejadian/ peristiwa lainnya.

Dari berbagai stasiun televisi, ada yang berperan sebagai media dokumentasi untuk pengkajian ilmu. Discovery Channel, National Geographic, dan Planet Animal adalah contoh saluran televisi yang menayangkan program dokumenter, misalnya menceritakan berbagai kejadian alam (letusan gunung berapi, banjir, tsunami, dan topan), peristiwa bersejarah di dunia seperti perkembangan kerajaan-kerajaan di Eropa, Asia, dan Afrika, serta beberapa penemuan-penemuan antropologi di masa lalu. Program acara ini dapat dijadikan alternatif sarana pembelajaran di samping belajar formal di dalam kelas dengan bermacam buku peserta didikan yang peserta didik pegang.

Bagi peserta didik yang mengalami masalah di area visual (kemampuan belajar dengan melihat) dan kuat di 
area audio (kemampuan belajar dengan mendengarkan), mereka dapat mengasah kemampuannya dengan menonton acara-acara tersebut. Keuntungan lainnya adalah, acara-acara tersebut disertai dengan fakta dan ilustrasi yang menarik berupa gambar-gambar dan rekaman peristiwa yang sebenarnya, sehingga kita bisa membayangkan dan menikmati seolah-olah hal tersebut memang benar-benar kita alami. Hal ini akan mempercepat kerja otak anak didik untuk menerima beberapa hal baru tentang pengetahuan dan meningkatkan kemampuan mereka berimajinasi secara kreatif.

Hasil penelitian Yayasan Pengembangan Media Anak (YPMA) tahun 2006 menunjukkan bahwa jumlah jam menonton televisi pada anak-anak usia sekolah dasar berkisar antara 30-35 jam seminggu, ditambah dengan sekitar 10 jam untuk bermain video game. Ini adalah jumlah waktu yang terlalu besar untuk hiburan yang kurang sehat bagi anak dan remaja. Dalam setahun, jumlah jam menonton televisi ini mencapai lebih dari 1.500 jam. Sedangkan jumlah jam belajar di sekolah dasar negeri selama 1 tahun hanya sekitar 750 jam (http://www.kidia.org/news/ tahun/2009/bulan/07/tanggal/01/id/ 114/ Diakses pada tanggal 14 Desember 2009).

Sungguh hebat peranan televisi dalam membangun karakter penontonnya, baik karakter positif maupun karakter negatif. Televisi menjadi guru yang begitu menawan di luar kelas bahkan menjadi saingan guru yang sesungguhnya dalam kelas. Menurut Jalaluddin Rahmat, televisi telah mampu mengubah atau mengatur pola hidup masyarakat (Rahmat, 1986). Sedangkan Darwanto Sastro Subroto mengemukakan bahwa televisi mempunyai karakteristik tersendiri yang tidak bisa dimiliki oleh media massa lainnya. Karakteristik audio visual yang dimiliki televisi mampu mempengaruhi penontonnya (Subroto, 1992).

\section{b. Internet}

Internet (international network) merupakan "a large collection of computers in network that are tied together so that many users can share their vast resources" (William, 1999). Sedangkan Kitao mengemukakan bahwa internet merupakan suatu jaringan komputer yang saling terkoneksi dengan jaringan komputer lainnya ke seluruh penjuru dunia (Kitao, 1998). Internet telah mengubah wajah komunikasi dunia yang sejak lama didominasi oleh perangkat digital non-komputer, seperti: telegram, telepon, fax, dan PBAX, menjadi komunikasi komputer yang global. Dengan pemanfaatan internet, seseorang di mana pun berada, dapat saling berhubungan dengan orang lain tanpa dibatasi lagi oleh ruang dan waktu.

Dengan kemajuan teknologi informasi dan komunikasi yang pesat, internet telah menjadi suatu medium belajar dan mengajar yang perlu diperhitungkan kemanfaatannya. Internet mempunyai potensi yang besar dalam pembelajaran, baik sebagai sumber belajar, media maupun pendukung pengelolaan proses belajar-mengajar (Koesnandar dkk., 2007). Mengingat berbagai ragam informasi dapat diperoleh dengan mudah dan cepat melalu internet di mana dan kapan saja, maka internet telah menjadi salah satu kebutuhan hidup seharihari. Bahkan melalui e-moderating yang tersedia di internet telah memungkinkan pengguna internet berkomunikasi dengan berbagai pihak secara mudah (Soekartawi, 2002).

Berdasarkan hal tersebut di atas dapatlah dikatakan bahwa internet 
sebagai media pendidikan mampu menghadapkan karakteristik yang khas, yaitu (1) sebagai media interpersonal dan massa, (2)

bersifat interaktif, dan (3)

memungkinkan komunikasi secara sinkron maupun asinkron. Karakteristik yang demikian ini telah memungkinkan peserta didik melakukan komunikasi dengan sumber ilmu secara lebih luas/ lengkap, mudah dan cepat dibandingkan dengan hanya menggunakan media konvensional.

Internet membantu peserta didik yang mengalami keterbatasan ruang dan waktu, untuk tetap dapat menikmati layanan pendidikan. Metoda talk and chalk dapat dimodifikasi dalam bentuk komunikasi melalui e-mail, mailing list, dan chatting. Mailing list dapat dianalogikan dengan "komunikasi bersama", di mana pakar akan berdiskusi bersama anggota mailing list. Metoda ini mampu menghilangkan jarak antara pakar dengan peserta didik. Suasana yang hangat dan nonformal pada mailing list ternyata menjadi cara pembelajaran yang efektif seperti pada metoda "tanya jawab".

\section{c. Dampak Negatif Media Televisi dan Internet}

Media elektronik (baca: televisi dan internet) merupakan media yang sangat digemari, tidak hanya oleh anak-anak tetapi juga para orang tua. Setiap media memiliki sumbangannya sendiri terhadap perkembangan manusia. Kekuatan dari salah satu jenis media belum tentu dimiliki oleh media lainnya. Dengan demikian, media dikatakan saling melengkapi satu dengan yang lainnya dan bukannya saling bertentangan. Pada dasarnya, bukan media yang membuat anak-anak malas, tetapi lebih cenderung pada para orang tua yang tidak atau kurang memberikan perhatian khusus terhadap perkembangan anak. Hal yang dibutuhkan sekarang adalah ide-ide positif yang dapat membuat media elektronik menjadi kekuatan konstruktif bagi pengembangan potensi anak-anak.

Televisi dan internet dapat pula digunakan untuk meningkatkan pemahaman dan kegemaran anak terhadap media cetak. Memang menarik bahwa film tidak hanya dapat merangsang pemahaman dan ingatan terhadap cerita, tetapi juga keinginan untuk membaca lebih banyak cerita yang serupa. Oleh karena itu, tidak ada alasan orang tua merasa takut mengenai kemajuan TIK yang memiliki sisi positif dan sekaligus juga sisi negatif. Para orang tua justru dituntut berikhtiar agar menjaga anak anak-anaknya tidak sampai terjerumus ke dalam sisi negatif teknologi.

"Media adalah pesan", kata ahli komunikasi Marshal McLuhan yang dirujuk oleh Yongky Karman (Kompas 15 September 2007). Dikemukakan lebih lanjut bahwa sebagai pembawa pesan, media (televisi, video game, komputer) bersifat netral: berpengaruh positif maupun negatif. Dalam kaitan pendidikan anak, para orang tua merasakan betapa sangat kuatnya dominasi media dewasa ini. Suka atau tidak, mau atau tidak, kemajuan TIK akan terus melanda kehidupan manusia. Yang perlu disikapi adalah bagaimana membekali anak agar dapat memaksimalkan pengaruh positif media dan sekaligus membentengi dirinya terhadap pengaruh negatif media dalam kehidupannya seharihari. Secara khusus lagi, para orang tua perlu menyikapi bagaimana caranya membantu anak agar memiliki persepsi yang kondusif dalam memanfaatkan media untuk memfasilitasi kegiatan pembelajaran.

Tampaklah betapa pentingnya peranan orang tua dan guru untuk mengarahkan anak agar mereka dapat memanfaatkan televisi dan 
komputer secara seimbang, baik untuk menunjang kegiatan pembelajaran, maupun untuk kepentingan rekreatif mereka. Tentulah kurang bijak manakala orang tua secara serta-merta hanya melarang atau menghalangi anakanak mereka untuk tidak boleh menggunakan kemajuan TIK.

Kebebasan stasiun televisi untuk menyajikan dan menayangkan program acara yang menarik untuk merebut perhatian penonton pada saat sekarang ini sudah sangat mengkhawatirkan. Program acara yang berbau kekerasan, pornografi, mistik dan kemewahan (hedonisme) dengan bebasnya dapat ditonton oleh siapapun tanpa memperhatikan dampaknya bagi pemirsa. Semuanya itu hanya untuk meningkatkan rating (http://www.kidia.org/news/tahun/ 2009/bulan/07/tanggal/21/id/120/ Diakses pada tanggal 20 Agustus 2009).

Manfaat televisi dalam membangun mental bangsa dapat dilihat dari bentuk atau jenis mata acara yang ditayangkan. Acara televisi seperti warta berita yang dikemas dalam berbagai nama, seperti Buletin Siang, Seputar Indonesia, News Flash, Metro Siang, Liputan Pagi, dan lainlain dapat memperluas khasanah pengetahuan masyarakat. Acara siaran Televisi dalam bentuk laporan dan bincang-bincang dapat memperkaya ranah kognitif dan affektif atau mental pemirsanya. Apabila diamati lebih lanjut, ada belasan stasiun televisi swasta yang saling berkompetisi melalui tawaran sajian berbagai acara yang dikemas secara menarik sehingga membuat para pemirsa betah untuk menontonnya.

Kondisi tersebut di atas terjadi karena misi utama televisi swasta bukan untuk mendidik masyarakat tetapi untuk menghibur dengan misi infotainment (informasi dan entertainment). Hiburan yang diberikan dapat berupa serangkaian film, yang ditayangkan mulai dari pagi sampai larut malam yang diselingi dengan berbagai iklan komersial. Kalau dicermati, ada sekitar 10 atau 11 film yang ditayangkan stasiun televisi setiap harinya. Kalau ada masyarakat yang sampai keranjingan menonton film, pastilah mereka akan menghabisan belasan jam waktunya di depan layar televisi setiap hari dan akan kehilangan saat-saat produktif dalam pengembangan dirinya.

Agaknya untuk menumbuhkan rasa kebangsaan dalam bentuk dorongan positif para generasi muda, pihak pengelola stasiun televisi bisa berbuat banyak. Misalnya dengan menyediakan kuota mata acara khusus dan menayangkan lagu-lagu kebangsaan "Indonesia Raya" dan lagu lagu nasional lain, seperti "Rayuan Pulau Kelapa", "Bandung Lautan Api", "Jembatan Merah", "Dari Sabang Sampai Merauke", dan lainlain. Namun dalam kenyataannya, para pengusaha industri media elektronik (pengelola stasiun televisi) masih kurang tergugah untuk mempromosikan lagu-lagu nasional dan lagu-lagu kebangsaan. Kenyataannya, lagu-lagu cinta yang cengeng dan bermesraan yang selalu mengumandang di layar televisi sehingga anak-anak balita malah hafal lagu-lagu cinta yang seyogianya tepat dikonsumsi para remaja/orang dewasa.

Haruslah diakui juga bahwa banyak mata acara televisi yang bagus. Filmfilm religi mendapat respon positif di masyarakat luas. Mata acara kuis, jelajah alam dan bincang-bincang cukup bagus untuk menambah wawasan pemirsa mereka. Namun disayangkan bahwa banyak juga masyarakat kita yang tidak memahami aturan menonton dan menghidupkan televisi, sampaisampai telah mencederai pendidikan 
anak-anak mereka. Sebagai contoh misalnya, anak-anak menjadi malas belajar dan beribadah gara-gara tayangan televisi jauh lebih menarik dan menggiurkan. Zaman sudah semakin aneh dan banyak orang menjadi entertainment oriented.

Memang inilah fenomena yang terjadi sekarang, mulai dari usia kanakkanak sampai ke usia sangat tua, banyak keluarga yang betul-betul gemar menonton. Isi mata acara yang disuguhkan TV yang berupa iklan dan hiburan berpotensi mendorong pemirsa dari seluruh lapisan umur untuk pro dengan gaya hidup mewah, hedonisme (ingin hidup serba senang) dan gaya hidup konsumerisme. Dampaknya, terjadi perubahan gaya hidup sebagian masyarakat. Dalam kaitan ini, Komisi Penyiaran Indonesia hendaknya melakukan penelitian tentang dampak dari berbagai acara siaran televisi yang "dinilai cenderung mengembangkan sikap atau gaya hidup konsumerisme, hura-hura, kekerasan, atau sikap hidup cengeng.

Sebuah survai yang pernah dilakukan harian Los Angeles Times membuktikan, 4 dari 5 orang Amerika menganggap kekerasan di televisi mirip dengan dunia nyata. Oleh sebab itu, sangat berbahaya kalau anakanak sering menonton tayangan televisi yang mengandung unsur kekerasan. Kekerasan di televisi membuat anak menganggap kekerasan adalah jalan untuk menyelesaikan masalah. Hasil survai yang dilakukan oleh Yayasan Pengembangan Media Anak pada tahun 2006 mengungkapkan bahwa jam menonton TV di kalangan anak jauh lebih besar porsinya dibandingkan dengan jumlah jam untuk belajar. Keadaan yang demikian ini tentunya sangat mengkhawatirkan tingkat perkembangan mental anak. Seperti yang diungkapkan Douglas Rushkoff, penulis buku Media Virus, bahwa televisi itu virus, memang ada benarnya (Rushkoff, 1996). Kritikus media lain menyatakan televisi sebagai candu elektronik, kotak idiot (idiot box), monster mata satu, dan lain sebagainya.

Penggunaan internet di Indonesia khususnya untuk kalangan peserta didik, baik di rumah maupun di sekolah sudah berkembang. Kota Jakarta, di mana para peserta didik mulai dari SD-SMU dan terlebih para mahasiswa sudah sangat familier menggunakan internet. Dalam kehidupan sehari-hari dapat diamati dominasi para peserta didik dan mahasiswa, di rumah maupun di sekolah dalam pemanfaatan internet. Ada kecenderungan akhir-akhir ini tentang pergeseran profil pengguna internet dan juga pergeseran orientasi pemanfaatannya.

Sebagian besar pengguna internet di kalangan peserta didik SMP, SMA, dan yang sederajat menggunakan internet untuk kepentingan game dan chatting. Peserta didik ini rela menghabiskan waktu pembelajaran 2x45 hanya untuk bermain internet dan menggunakan situs yang lagi fenomenal: facebook. Pergeseran orientasi penggunaan internet tampaknya belum sepenuhnya tertangkap oleh para orang tua karena terbukti bahwa apabila anak meminta uang berapapun untuk bermain internet selalu diberikan orang tua. Padahal yang terjadi tidak ada unsur pendidikan apapun yang bisa didapatkan dari bermain game dan chatting. Memang tidak semua peserta didik menggunakan internet untuk bermain game dan chatting, namun efek kecanduan telah membuat anak malas belajar.

Bahkan sekarang ini internet sudah dijadikan sarana bagi para pelaku pedofilia untuk menjaring calon mangsa. Dengan kepiawaian mereka memainkan perasaan anak 
perempuan yang masih lugu, mereka memberikan dorongan psikologis yang cukup kuat untuk menjebak korbannya menuruti kemauan mereka. Hal yang paling mengkhawatirkan baik anak-anak, remaja bahkan orang dewasa adalah dengan bebasnya berselancar di dunia maya untuk mengakses situssitus pornografi. Tentu hal ini akan menjadi masalah besar bagi pertumbuhan dan perkembangan psikologis anak.

\section{Peranan Orang Tua dan Guru dalam Pengembangan Diri Anak terhadap Dampak Negatif Teknologi Informasi dan Komunikasi}

\section{a. Orang Tua}

Beberapa dampak negatif (bahaya) dan masalah kecanduan internet bukanlah sesuatu yang harus ditakuti oleh para orang tua tetapi membutuhkan tindakan untuk mencegahnya. Berikut ini disajikan beberapa tips yang perlu mendapat perhatian para orang tua untuk mencegah anak dari dampak negatif dan bahaya kecanduan pemanfaatan internet (http://kumpulan.info/ keluarga/anak/40-anak/165-lindungianak-dari-bahaya-internet.html):

1) Berupaya Memiliki Pengetahuan tentang Internet

Orang tua perlu belajar mengenai internet setidak-tidaknya mempunyai pemahaman tentang dampak negatif dari internet. Dengan pemahaman yang sekalipun minimal ini orang tua akan dapat mengawasi/ mengarahkan anak-anaknya dalam memanfaatkan internet. Salah satu penyebab anak menyukai internet adalah karena mereka mendapatkan pengalaman baru, berada di dunia maya. Di dunia maya, seorang anak bisa menjadi orang lain yang diinginkan. Misalnya, seorang anak yang pemalu dapat dengan mudah berkenalan melalui chating atau e-mail. Dalam game online, anak-anak dapat membuat karakter mereka sebagai anak yang berkarakter cantik, kaya, atau hal lain yang mungkin berbeda dengan kehidupan nyata mereka.

2) Meletakkan Komputer di Tempat yang Mudah Dilihat

Kadang-kadang orang tua merasa bangga dapat meletakkan sebuah komputer yang terkoneksi dengan internet atau pesawat televisi di dalam kamar anak mereka. Hal ini sebenarnya akan membahayakan karena anak akan dapat dengan leluasa mengakses situs-situs yang tidak baik tanpa diketahui orang tua. Demikian juga dengan membuka saluran siaran televisi yang bukan diperuntukkan bagi konsumsi anak. Sebaliknya, dengan meletakkannya di tempat terbuka, misalnya di ruang keluarga, maka orang tua akan dapat memantau situs yang diakses dan tayangan siaran televisi yang ditonton anak.

3) Membantu Anak Membuat Keputusan Sendiri

Tentunya orang tua tidak dapat mengawasi anaknya selama 24 jam. Oleh karena itu, orang tua hendaknya membiasakan anak untuk mengambil keputusan mulai dari hal-hal yang kecil. Misalnya, memutuskan untuk menggunakan pakaian yang akan dipakai atau menanyakan pendapat dan sudut pandang mereka tentang berbagai hal. Jika seandainya anak kebetulan menemukan situs porno di internet, mereka diharapkan akan dapat mengambil tindakan yang tepat. Di samping itu, para orang tua juga haruslah menanamkan rasa takut akan Tuhan sehingga 
anak-anak mereka meyakini bahwa Tuhan senantiasa memperhatikan apa yang mereka lakukan.

4) Membatasi Penggunaan Internet Mengakses internet terutama games dapat membuat seorang anak betah berlama-lama dan bahkan bisa lupa makan dan belajar. Oleh karena itu, anakanak jangan dibiarkan terlalu asyik di dunia maya. Haruslah ditetapkan berapa lama internet boleh digunakan dan situs apa saja yang boleh diakses. Pembatasan waktu dan situs internet yang boleh diakses haruslah dijelaskan kepada anak agar mereka dapat mengerti dan menerimanya.

5) Menjaga Komunikasi yang Baik dengan Anak

Semua orang tua menyayangi anak mereka dan berusaha memberikan yang terbaik. Sehubungan dengan hal ini, para orang tua perlu meluangkan waktu untuk bercanda dan berkomunikasi secara terbuka dengan anak. Komunikasi yang baik dan akrab akan memudahkan orang tua untuk menanamkan nilai-nilai moral kepada anak. Mengingat pengaruh dari luar (salah satunya bahaya internet, seperti: pornografi dan para pemangsa atau predator seksual) juga sangat besar terhadap kehidupan anak, maka orang tua juga haruslah menjelaskan kepada anak tentang bahaya penggunaan internet agar mereka tidak mudah terkecoh sehingga bahaya internet tidak sampai merusak kecerdasan dan nilai moral mereka.

\section{b. Sekolah (Guru)}

Peranan guru di era teknologi informasi dan komunikasi (TIK) juga menjadi perhatian utama dalam pendidikan anak. Adalah menjadi tanggung jawab guru sebagai pendidik di sekolah dan sekaligus juga menjadi modal utama sekolah dalam mengarahkan anak yang menjadi peserta didiknya untuk menjadi orang yang mampu menggunakan TIK. Untuk itu, diperlukan perhatian pemerintah untuk meningkatkan sumber daya guru di bidang pendayagunaan TIK.

Ada tiga hal yang harus diwujudkan dalam rangka memperbaiki mutu pembelajaran melalui pemanfaatan TIK, yaitu (a) peserta didik dan guru harus memiliki akses pada teknologi digital dan internet di dalam kelas, sekolah, dan lembaga pendidikan guru, (b) tersedianya materi pelajaran (konten) yang berkualitas, bermakna, dan dukungan kultural bagi peserta didik dan guru, dan (c) guru harus memiliki pengetahuan dan keterampilan menggunakan peralatan/fasilitas digital untuk membantu membelajarkan peserta didik mencapai standar akademik yang ditetapkan.

Sejalan dengan pesatnya perkembangan TIK, telah terjadi pula pergeseran pandangan (paradigma) tentang pembelajaran, baik di dalam maupun di luar kelas. Dalam pandangan tradisional di masa lalu (dan masih terasakan pada masa sekarang), proses pembelajaran dipandang sebagai sesuatu yang sulit dan berat, suatu proses transfer dan penerimaan informasi, kegiatan yang dilakukan dengan menjabarkan materi pelajaran menjadi satuansatuan yang lebih kecil, dan suatu proses linear.

Pergeseran paradigma tentang pembelajaran juga telah mengubah peranan guru dan peserta didik dalam kegiatan pembelajaran. Peranan guru telah berubah dari yang semula (a) sebagai pemberi pengetahuan, sumber utama informasi, ahli materi, dan sumber segala jawaban, menjadi 
fasilitator pembelajaran, pelatih, kolaborator, navigator pengetahuan, dan mitra belajar, dan (b) mengendalikan dan mengarahkan semua aspek pembelajaran, menjadi cenderung memberikan lebih banyak alternatif dan tanggung jawab kepada setiap peserta didik dalam proses pembelajaran (http:// www. penapendidikan.com/ pergeseran-paradigma-pendidikan/).

Sementara itu, peran peserta didik dalam pembelajaran juga telah mengalami perubahan, yaitu dari yang semula (a) s e b a g a i penerima informasi yang pasif menjadi partisipan aktif dalam proses pembelajaran, (b) mengungkapkan kembali pengetahuan menjadi menghasilkan dan menyajikan berbagai pengetahuan, dan (c) hanya memandang pembelajaran sebagai aktivitas individual (soliter) menjadi pembelajaran berkolaboratif dengan peserta didik lainnya (http:// bennisetiawan.blogspot.com/2008/ 08/matinya-peran-pendidik.html).

\section{PENUTUP}

\section{Kesimpulan dan Saran}

Pertumbuhan anak mulai dari usia dini hingga dewasa tidak terlepas dari tanggung jawab orang tua. Orang tua yang lebih peka dan tahu tentang pertumbuhan dan perkembangan anak. Peranan orang tua dan guru terhadap pendidikan anak di era teknologi informasi dan komunikasi (TIK) sangat penting, baik di sekolah dalam berkomunikasi dengan pihak sekolah, di rumah maupun di lingkungan anak bersosialisasi. Kemajuan TIK sangat besar peranannya dalam proses pendidikan dan kehidupan anak karena anak dapat dengan begitu bebasnya mencari/memperoleh dan memanfaatkan ilmu pengetahuan dan informasi lainnya termasuk juga kecenderungan untuk mencari informasi yang negatif.
Kemajuan TIK memberikan kontribusi yang besar terhadap perluasan wawasan, baik yang mengarah pada jasa ilmu pengetahuan maupun jasa ilmu kemurtatan. Oleh karena itu, peranan orang tua sangat dituntut untuk tetap mengawasi perkembangan anak di lingkungan keluarga. Anak sejak dini perlu diperkenalkan dengan perkembangan TIK dan membimbing mereka untuk mengembangkan hal-hal yang benar-benar bermanfaat (positif) bagi perkembangan anak, baik di lingkungan keluarga maupun sekolah.

\section{Saran}

Mengingat pendidikan anak sangat banyak tergantung pada peranan orang tua dan guru, maka disarankan agar para orang tua dan guru menjalin kerjasama yang baik dan teratur agar perkembangan anak lebih terpantau. Apabila terjadi masalah yang dialami anak, maka dengan adanya kerjasama yang baik dan teratur, permasalahan yang dihadapi anak dapat dengan segera diatasi. Mengingat kemajuan TIK yang sedemikian pesatnya dewasa ini yang memungkinkan anak-anak dapat dengan mudah dan leluasanya mengaksesnya, maka para orang tua disarankan agar lebih mencermati kegiatan anak, baik dalam memanfaatkan siaran televisi di rumah maupun dalam mengakses internet.

\section{DAFTAR PUSTAKA}

Blooger : http://bennisetiawan.blogspot.com/ 2008/08/matinya-peran-pendidik.html. Diakses 18 Januari 2010)

Fathul Wahid. (2005). Peran Teknologi Informasi Dalam Modernisasi Bangsa. Simposium Nasional Peduli Pendidikan yang diadakan oleh pendidikan@yahoogroups.com, di Fakultas Teknologi Industri, Universitas Islam Indonesia, Yogyakarta.

Guntarto B. 2009. Info Lengkap Hari Tanpa TV Sumber dari Internet: (http://www.kidia.org/ news/tahun/2009/bulan/07/tanggal/01/id/114/ Diakses pada tanggal 14 Desember 2009).

Karman, Yonky. 2007. Berhenti Berpikir Cara 
Televisi. Harian Umum Kompas terbitan 15 September 2007.

Kemp, J. E. and Dayton, O. K. (1985). Planning and Producing Instructional Media. New York: Harper \& Row Publisher, Inc.

Khoirul Akmal, SPd. (2009).

Kecenderungan Global dalam Pemanfaatan Teknologi Informasi dan Komunikasi untuk Pendidikan di Indonesia.

Kitao, Kenji. 1998. Internet Resources: ELT, Linguistics, and Communication. Japan: Eichosha.

Koesnandar, Uwes Chaeruman, dan Ika Kurniawati. 2007. Studi Pemanfaatan EdukasiNet di Sekolah. Sumber: http:// www.e-dukasi.net/artikel/index.php?id=46. Diakses pada tanggal 20 Agustus 2007.

Marshal McLuhan. (2003). Understanding Media: The Extensions of Man; 1st Ed. McGraw Hill, NY; reissued MIT Press, 1994, with introduction by Lewis $\mathrm{H}$. Lapham; reissued by Gingko Press.

Lie, A. (2004). "Pendidikan dalam Dinamika Globalisasi" dalam Widiatono, T. D. Pendidikan Manusia Indonesia.

Rahmat, Jalaluddin. (1986). Psikologi Komunikasi. Bandung: PT. Remaja Rosdakarya.

Rushkoff, Douglas. (1996). The Media Virus. Manufactured in the United States of America. First Trade Paperback. Edition February 1996.
Siahaan, Sudirman. 2006. Internet, Guru, dan Pembelajaran. Jakarta: Pusat Teknologi Informasi dan Komunikasi PendidikanDepartemen Pendidikan Nasional.

Soekartawi. 2002. E-learning: Konsep dan Aplikasinya. Bahan Ceramah yang Disajikan pada Seminar yang Diselenggarakan Balitbang Depdiknas. Jakarta: BalitbangDepdiknas, 18 Desember 2002.

Soeparno. (1988). Media Pengajaran Bahasa. Klaten: Intan Pariwara.

Subroto, Darwanto Sastro. (1992). Televisi sebagai Media Pendidikan. Salatiga: Duta Wacana University Press.

Website : http://www.gobatak.com, Sumber: Internet. Diakses pada tanggal 20 Agustus 2009.

Website : http://kumpulan.info/keluarga/anak/40anak/165-lindungi-anak-dari-bahayainternet.html. Sumber: Internet. Diakses pada tanggal 20 Agustus 2009.

Website : (http://kumpulan.info/keluarga/ anak/40-anak/192-pendidikan-yang-baikuntuk-anak.html. Diakses 20 Agustus 2009).

Website : http://www.penapendidikan.com/ pergeseran-paradigma-pendidikan/. Diakses 20 Agustus 2009

Williams, Bard, 1999, The Internet For Teachers, 3rd Edition, IDG Books Worldwide, USA

Widyo Nugroho, Meilani Siregar, Sri Wiji Lestari, Perancangan Media Video Pembelajaran Berbasis Web (Studi Kasus Mata Kuliah Pengantar Teori Graph). Jakarta: Gunadarma University, Margonda Raya, Depok. 